\title{
Role of prokinetic agents in the treatment of gastroesophageal reflux disease
}

\author{
MICHEL BOIVIN, MD, FRCPC
}

\begin{abstract}
M Borvin. Role of prokinetic agents in the treatment of gastroesophageal reflux disease. Can J Gastroenterol 1993;7(5):414-416. Most of the factors contributing to the development of reflux esophagitis (eg, transient lower esophageal sphincter relaxations, low basal pressure of the lower esophageal sphincter, impaired esophageal clearance and delayed gastric emptying) are related to upper gastrointestinal dysmotility. Prokinetic agents are able to counterbalance these motor derangements and are therefore useful in the medical treatment of gastroesophageal reflux disease.
\end{abstract}

Key Words: Cholinergic agonist, Dopamine antagonists, Gastroesophageal reflux, Lower esophageal sphincter (LES), Prokinetic agents

\section{Le rôle des agents procinétiques dans le traitement du reflux gastro-œesophagien}

RÉSUMÉ: Des anomalies de motricité, comme par exemple, une relaxation innappropriée du sphincter oesophagien inférieur, une hypotonie du sphincter cesophagien inférieur, des anomalies de contractions de l'œesophage et un retard de vidange gastrique, sont tous des facteurs pouvant contribuer au reflux gastrooesophagien et par conséquent à l'oesophagite. L'utilisation d'agents procinétiques qui en corrigeant ces anomalies motrices s'avère donc un traitement efficace et global du reflux gastro-øesophagien.

$\mathrm{T}$ HE CURRENT LITERATURE INDI. cates that most of the factors which contribute to the development of reflux esophagitis depend on motility disorders of the esophagus or stomach. However, some studies suggest that impairment of esophageal mucosal defence and increased aggressiveness of gastric juice may be contributory fac- tors in some patients. The motor defects that lead to reflux disease cause both abnormally frequent gastroesophageal reflux episodes and slow clearance of the refluxed material from the esophagus back into the stomach. This defective functioning causes excessive exposure of the distal esophagus to refluxate.

Gastroenterology Unit, Centre de recherche clinique, André-Viallet, Hôpital Saint-Luc, Montréal, Québec

Correspondence: Dr Michel Boivin, Hopital Saint-Luc, Centre de recherche clinique André-Viallet, 264, René-Lévesque est, Montréal, Québec H2X IP1. Telephome (514) 281-2472, Fax (514) 281-2492

Reflux episodes occur as a consequence of an incompetent lower esophageal sphincter (LES) which may manifest as intermittent inappropriate relaxations or, in more severe forms of the disease, as chronically low basal pressure. It appears that abnormally frequent transient LES relaxations, which are clearly distinguished from relaxations induced by normal swallowing, are the most important mechanism of gastroesophageal reflux. However, this hypothesis needs to be investigated further by monitoring esophageal motility and $\mathrm{pH}$ in ambulatory patients with reflux disease. In addition, it must be recalled that impaired esophageal clearance resulting in prolonged esophageal acid exposure contributes to the development of esophagitis. Delayed gastric emptying can also contrib. ute to the development of reflux dis. ease. This functional disorder allows the pathological retrograde flow of gastric contents into the distal esophagus. One logical approach to therapy would be to enhance the functioning of the LES sphincter and the propulsive function of the body of the esophagus. The use of prokinetic agents, which increase LES tone, enhance esophageal peristaltic contractions and stimulate gastric emptying, is appealing in the management of gastroesophageal reflux disease (GERD) because it addresses the chronic underlying factors that contribute to the condition.

Prokinetic agents (Table 1) influ- 
ence gastrointestinal (Gi) motility through one or more of the following pathways: directly or indirectly by promoting cholinergic tone; by antagonizing inhibitory neurotransmitters (eg, serotonin, dopamine).

\section{CHOLINERGIC AGONIST}

Bethanechol was the first prokinetic agent to be used to treat patients with GERD. Bethanechol is a cholinergic agonist which acts almost entirely at the muscarinic receptors, with little if any effect on nicotinic receptors. The agent increases LES pressure and esophageal clearance, but has little effect on gastric emptying (1). It also stimulates the secretion of saliva which may contribute to improved symptoms by the buffering action of saliva on gastric refluxate. Studies with the use of bethanechol in GERD have produced conflicting results $(2-4)$, with clinical trials showing improvement in symptoms and in endoscopic esophagitis in the range of 40 to $50 \%$. The dose of bethanechol used for the treatment of GERD ( $25 \mathrm{mg}$ qid) is often not well tolerated because of side effects. The side effects, which develop as a result of enhanced parasympathetic tone, include abdominal cramps, diarrhea, salivation, flushing, bradycardia and blurred vision. They occur in 10 to $30 \%$ of patients thus limiting the use of bethanechol in the treatment of GERD.

\section{DOPAMINE ANTAGONISTS}

Metoclopramide mainly stimulates GI motility through dopamine receptor blockage and facilitation of acetylcholine release from post ganglionic cholinergic nerve terminals. The usefulness of metoclopramide in treating reflux is suggested by its effects on LES pressure (5), by increasing the amplitude of esophageal contraction and by improving gastric emptying $(6,7)$. Controlled studies showed that metoclopramide improved symptoms (heartburn and regurgitation) and the need for antacid use in patients with GERD $(8,9)$. Also a study comparing the efficacy of either metoclopramide $(10 \mathrm{mg}$ tid) or ranitidine ( $150 \mathrm{mg}$ bid) showed that both drugs were effective in producing symptomatic and endoscopic improvement (10). Clinical trials with metoclopramide showed improvement of symptoms and esophagitis in a range of 40 to $60 \%$. However, side effects were reported to occur in 10 to $20 \%$ of patients. The most troublesome side effects, particularly those related to the central nervous system (CNS) (agitation, somnolence and extrapyramidal symptoms), have limited its use (6).

Domperidone is a benzimidazole derivative that specifically antagonizes the inhibitory effects of dopamine on the upper intestinal tract. It is distinguished from other prokinetic agents in that it has no cholinergic activity. Unlike metoclopramide, domperidone has limited ability to cross the blood-brain barrier and therefore causes fewer CNS side effects. Side effects such as increased prolactin levels and gynecomastia are observed occasionally. Most studies with domperidone suggest that its effect in patients with reflux esophagitis may be due to improved gastric emptying (11) rather than improved esophageal motility and LES pressure $(12-14)$. Some clinical trials showed that domperidone is equivalent to ranitidine in producing symptomatic and endoscopic improvement $(15,16)$. However, other studies showed that domperidone produced limited improvement of symptoms (frequency of heartburn and incidence of reflux episodes) $(11,17,18)$. At present, there are few reported studies showing clear beneficial effects of domperidone in patients with GERD using the standard dose of $10 \mathrm{mg}$ tid or qid. However, increasing the dose of domperidone to $20 \mathrm{mg}$ qid may be more effective in the treatment of patients with GERD.

\section{SUBSTITUTED BENZAMIDES}

Cisapride promotes GI motility and increases antroduodenal coordination by releasing acetylcholine from enteric neurons. Pharmacological studies have clearly shown that cisapride increases low LES pressure to normal values (19), improves the contractile activity of the esophagus (20-22) and increases gastric emptying rates (23).

Clinical studies on the use of cisapride in the treatment of GERD have shown that the agent improves symp-

\section{TABLE 1}

Prokinetic agents

Cholinergic agonist

Bethanechol

Antidopaminergics

Metoclopramide

Domperidone

Substituted benzamides

Cisapride

toms and promotes esophageal healing (24-27). Rates of cure, measured objectively by endoscopy, were obtained in 63 to $85 \%$ of patients in clinical trials. Similar results in symptomatic im. provement were obtained as well.

Other studies showed that cisapride is at least as effective as either ranitidine or metoclopramide in the treatment of GERD $(28,29)$. In an American-Canadian multicentre study (30), cisapride improved symptom scores, particularly in patients with low LES pressure suffering from moderate to severe heartburn.

The dose used in clinical studies with cisapride is $10 \mathrm{mg}$ qid, which can, in some cases, impair patient compliance. Geldof et al (31) compared two dose regimens of cisapride $(10 \mathrm{mg}$ qid and $20 \mathrm{mg}$ bid) with ranitidine (150 $\mathrm{mg}$ bid) in a double-blind controlled trial. All treatments proved equally effective in improving the endoscopically confirmed healing of esophagitis. These results suggest that administration of the medication twice a day may be as effective as four times a day.

In clinical trials, a transient increase in stool frequency was the only side effect reported more frequently than in patients receiving placebo. Given its excellent safety profile, cisapride could have a promising role in long term maintenance therapy for reflux, possibly in a twice-a-day or bedtime dose regimen (32).

\section{CONCLUSION}

GERD can be regarded as a motility disorder. Although blocking acid is an effective treatment for reflux, it does not overcome the underlying pathologic factor of GERD. By their effect on motor disturbances, prokinetic agents have an important role in the treatment of GERD. There is clear evidence that 
these agents improve both subjective symptoms due to gastroesophageal reflux as well as the endoscopic and histological evidence of mucosal inflammation. These benefits are mediated through the effects of prokinetic agents on LES, esophageal motility and gastric emptying. Clinical studies

\section{REFERENCES}

1. McCallum RW, Fink SM, Lemer E, et al. Effects of metoclopramide and bethanechol on delayed gastric emptying in gastroesophageal reflux patients. Gastroenterology 1983;84:1573.

2. Thanik KD, Chey WY, Shaf AY, et al. Reflux esophagitis: Effect of oral bethanechol on symptoms and endoscopic findings. Ann Intern Med 1980;93:805.

3. Saco LS, Orlando RC, Levinson SL, et al. Double-blind controlled trial of bethanechol and antacid versus placebo and antacid in the treatment of erosive esophagitis.

Gastroenterology 1982;82:1369.

4. Thanik KD, Chey WY, Shah AN, et al. Bethanechol or cimetidine in the treatment of symptomatic reflux esophagitis. Arch Intern Med 1982;142:1479-81.

5. Wallin L, Boesby S, Madsen I. Effect of metoclopramide on oesophageal peristalsis and gastroesophageal sphincter pressure. Scan J Gastroenterol 1979;14:923

6. Albibi R, McCallum RW.

Metoclopramide: pharmacology and clinical application. Ann Intern Med 1983;98:86-95.

7. McCallum RW, Fink SM, Lerner E, et al. Effects of metoclopramide and bethanechol on delayed gastric emptying present in gastroesophageal reflux patients. Gastroenterology 1983;84:1573-7.

8. McCallum RW, Ippolitti AF, Cooney C, et al. A controlled trial of metoclopramide in symptomatic gastroesophageal reflux. N Engl J Med 1977;296:354-7.

9. McCallum RW, Kline MM, Curry N, et al. Comparative effects of metoclopramide and bethanechol on lower esophageal sphincter pressure in reflux patients. Gastroenterology 1975;68:1114-8.

10. Guslandi M, Testoni PA, Passaretti A, et al. Ranitidine vs metoclopramide in the medical treatment of reflux esophagitis. Hepatogastroenterology 1983;30:96-9.

11. Champion MC, Hartnett M, Yen M. with metoclopramidedemonstrated its efficacy in the treatment of GERD but troublesome side effects have limited its use. Limited trials with domperidone have shown some evidence of efficacy in GERD, but its overall usefulness in controlling reflux symptoms and healing esophagitis is not well established.

Domperidone, a new dopamine antagonist. Can Med Assoc J 1986;135:457-61.

12. Blackwell JN, Heading RC, Fettes MR. Effects of domperidone on lower esophageal sphincter pressure and gastroesophageal reflux in patients with peptic esophagitis. R Soc Med Int Gong Symp Series 1981;36:57-65.

13. Valenzuela JE. Effects of domperidone on the symptoms of reflux esophagitis. R Soc Med Int Cong Symp Series 1981;36:51-6.

14. Weihrauch TR, Forster CRF, Krieglstein J. Evaluation of the effect of domperidone on human esophageal and gastroduodenal motility by intraluminal manometry. Postgrad Med J 1979;55:7-10.

15. Masci E, Testoni PA, Pasaretti S, et al. Comparison of ranitidine,

domperidone maleate and ranitidine and domperidone maleate in the short term treatment of reflux esophagitis. Drugs Exp Clin Res 1985;10:1-6.

16. Goethals C. Domperidone in the treatment of postprandial symptoms suggestive of gastroesophageal reflux. Curr Ther Res 1979;26:874-80.

17. Schulze-Delrieu K, Summers RW, Find D. Domperidone in reflux oesophagit is and gastric stasis. Lancet 1981;i:159.

18. Champion MC. Domperidone: Minireview. Gen Pharmacol 1988;19:499-505

19. Janssens J, Ceccatelli P, Vantrappen G. Cisapride restores the decreased lower esophageal sphincter pressure in reflux patients. Digestion 1986;34:139.

20. Wienbeck M, Cuder-Weisinger E, Berges W. Cisapride acts as a motor stimulator in the human esophagus. Gastroenterology 1984;86:1298.

21. Gilbert RJ, Dodds WJ, Kahrilas PJ, et al. Effect of cisapride, a new prokinetic agent, on esophageal motor dysfunction. Dig Dis Sci 1987;32:1331-6.

22. Wienbeck M, Cuder-Weisinger E, Berges W. Cisapride acts as a motor stimulator in the human esophagus. Gastroenterology 1984;86(5, parr 2):1298A.

23. Jian R, Ducrot F, Piedeloup C, Mary JY, Najean Y, Bernier J]. Measurement
In contrast, clinical studies have shown that cisapride markedly improves symptoms and promotes esophageal healing in patients with (AERD). This suggests that cisapride is the treatment of choice when considering a prokinetic agent in the treatment of patients with GERD.

of gastric emptying in dyspeptic patients: Effect of a new gastrokinetic agent (cisapride). Gut 1985;26:352.

24. Lepoutre L, Bollen J, Vandewale N, et al. Therapeutic side effects of cisapride in reflux oesophagitis: A double-blind, placebo-controlled study. In: Progress in the Treatment of Gastrointestinal Motility Orders. Amsterdam: Excerpta Medica, 1988:63-5.

25. Van Outrye M, Vanderlinden I, Dedullen G, et al. Dose-response study with cisapride in gastroesophageal reflux disease. Curr Ther Res 1988:43:408-15.

26. Cucchiara S, Staiano A, Capozzi C, et al. Cisapride for gastro-oesophageal reflux and peptic oesophagitis. Arch Dis Child 1987;62:454-7.

27. Baldi F, Bianchi-Porro G, Dohrilla G, et al. Cisapride versus placebo reflux oesophagitis. A multicenter double-blind trial. J Clin Gastroenterol 1988;10:614-8.

28. Janisch JD, Huttemann W, Bouzo MH. Cisapride versus ranitidine in the treatment of reflux esophagitis. Hepatogastroenterology 1988;35:125-7.

29. Rode H, Stunden RJ, Millar AJW, et al. Esophageal $\mathrm{pH}$ assessment of gastroesophageal reflux in 18 patients and the effect of two prokinetic agents; cisapride and metoclopramide.

J Pediatr Surg 1987;22:931-4.

30. Dodds W, Champion N, Orr W, et al. Oral cisapride in GERD: A doubleblind placebo-controlled multicenter trial. Gastroenterology 1989;96:A126.

31. Geldof H, Otten MH, Hazelhoff B, Reyntjens A. Double-hlind comparison of the effect of two dosage schedules of cisapride with that of ranitidine on endoscopic healing rates in reflux oesophagitis. $\mathrm{ln}$ : World Congress of Gastroenterology. Digestive Endoscopy and Colo-Proctology. Sydney, Australia, August 26-31, 1990. (Abst)

32. Tytgat GNJ, Anker Hansen OJ. Carling L, et al. Effect of cisapride on relapse of reflux esophagitis healed with an antisecretory drug. Scand J Gastroenterol 1992;27:175-83. 


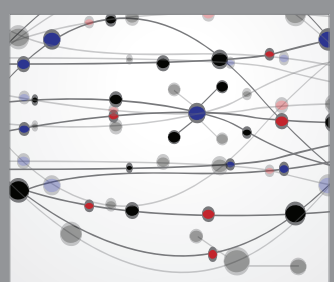

The Scientific World Journal
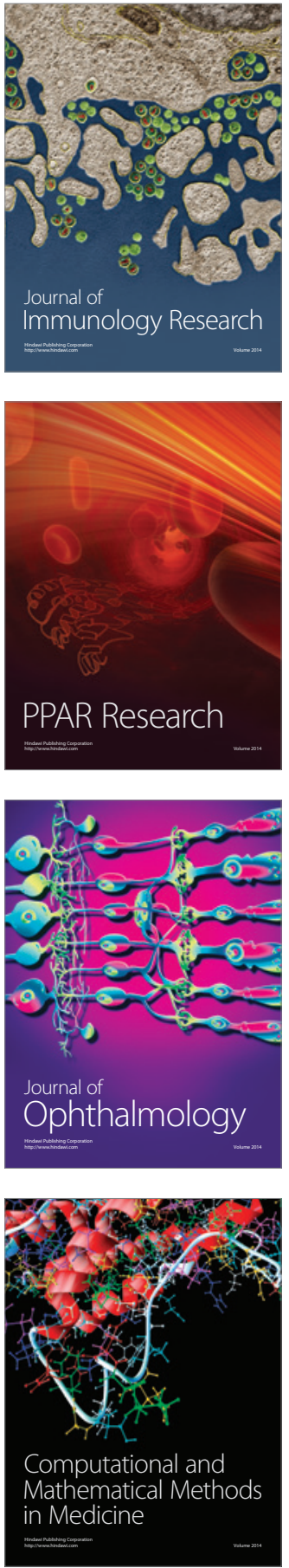

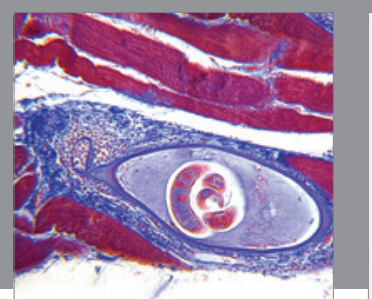

Gastroenterology Research and Practice

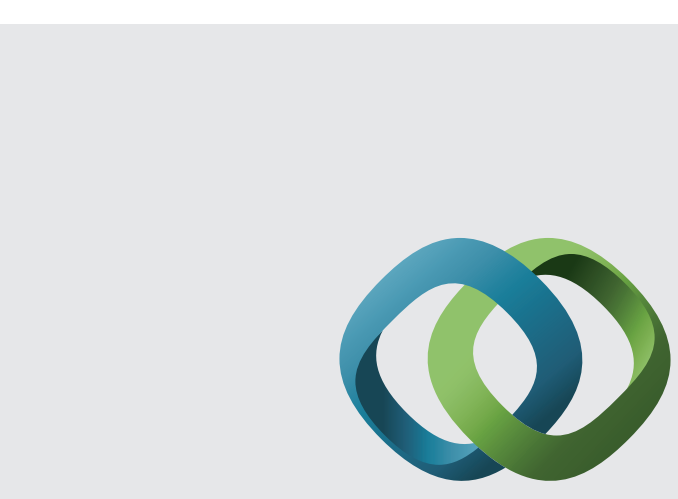

\section{Hindawi}

Submit your manuscripts at

http://www.hindawi.com
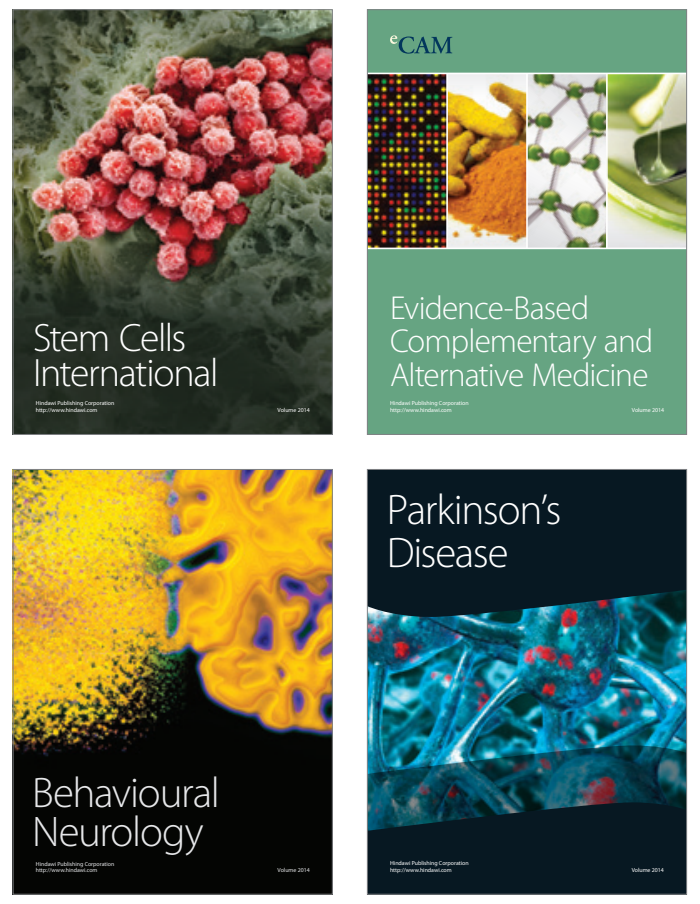
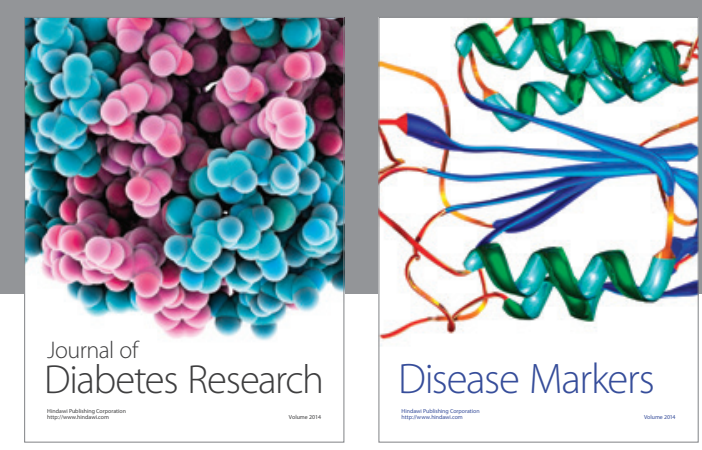

Disease Markers
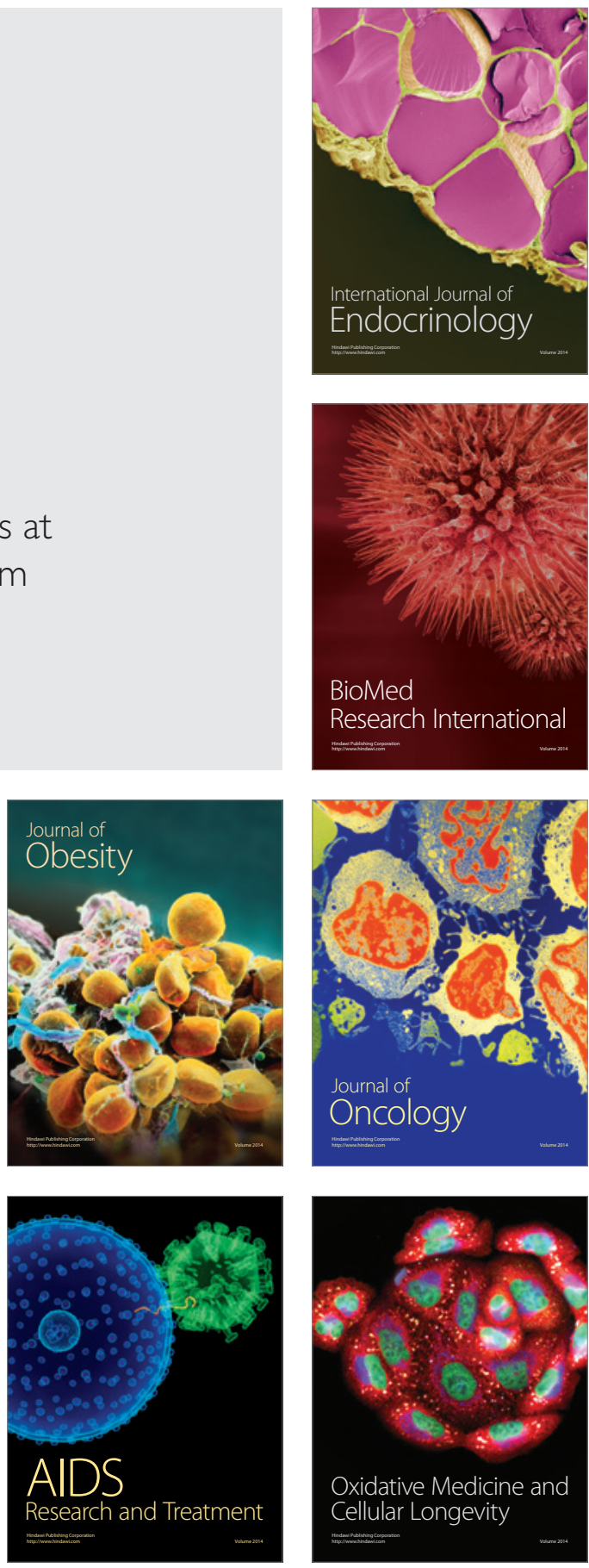